\title{
Enhancing College Students' Science Process Skills Through RICOSRE Learning Model
}

\author{
Deny Setiawan ${ }^{1 *}$, Susriyati Mahanal ${ }^{1}$, Siti Zubaidah ${ }^{1}$ \\ ${ }^{1}$ Biology Department, Faculty of Mathematics and Science, PUIPT Disruptive Learning Innovation, Universitas Negeri \\ Malang, Indonesia \\ ${ }^{*}$ Corresponding author. Email: setiawan.fmipa@um.ac.id
}

\begin{abstract}
Science and science instruction contains basic concepts of science as well as science process skills, which underlie the process of thinking scientifically that involves cognitive and investigation skills. Science process skills can be acquired and developed through learning. RICOSRE is one of the learning models that can be used to promote science process skills. This study aimed to investigate 1) an increase in students' science process skills during the implementation of RICOSRE, and 2) the effect of RICOSRE on students' science process skills in a Protista course. Concurrent triangulation design was employed in this study. The qualitative data analysis was performed using descriptive analysis, while t-test was conducted to analyze the quantitative data. The data were collected from the participants' answers to essay questions found in the pretest, mid-test, and post-test. The results of analyses showed that students' average scores improved by $19.10 \%$ from the pretest to the mid-test and by $20.83 \%$ from the mid-test to the post-test. It was also found that RICOSRE had an effect on the students' science process skills (at a significance level of $0.000<0.05$ ). The findings of the study, therefore, suggest that RICOSRE can be used to improve students' science process skills.
\end{abstract}

Keywords: RICOSRE, Science Process Skills

\section{INTRODUCTION}

Twenty-first-century learning typically focuses on understanding, analyzing, and solving everyday problems effectively. University or college students need to develop a set of skills and abilities to be able to live in society. One of the skills that have to be mastered by the students is science process skills. Science process skills involve the ability to ask questions in science and discover proper answers to the questions. These skills are not only useful in science but also the in students' daily lives and future.

However, facts show that the majority of university students have poor science process skills. An observation conducted over three years (2015-2018) in a Protista course at the Department of Biology, Universitas Negeri Malang indicated that the students were unable to perform an indepth identification of an organism. Limited practicum experience and inadequate facilities resulted in the inability of the students to relate their findings to existing theories on Protist characteristics. As a result, the students could not achieve the desirable competencies, nor satisfactory scores in practicum tests, theory tests, and practicum reports. This was indicated by their low achievement in Protist tests during the 2015-2018 period, where the students achieved an average score of 58 in 2015, 64 in 2016, and 60 in 2017. Describing specimens were reported as the most frequent problem found by the students during the practicum tests. Science process skills are essential skills in scientific investigations, learning processes, and student research [1]. Science process skills consist of competencies that must be mastered and applied by university students through physical and mental activities so that science can be more effective in problem solving as well as individual and social development [2], [3]. Science process skills involve the ability to use thinking in collecting information [4] and aim to help students identify, observe, analyze, and hypothesize problems, draw a conclusion, and implement knowledge in real life [5]. Science process skills can be classified into basic and integrated science process skills. Basic science process skills are identified as the prerequisite skills of integrated science process skills [6]. Therefore, to develop integrated science process skills that can be used to solve problems and do experiments [6], students need to acquire basic knowledge of science [3].

Integrated science process skills are divided into five indicators consisting of several descriptors. The first indicator is identifying and controlling variables. This indicator consists of five descriptors that are identifying independent variables, identifying dependent variables, identifying control variables, identifying extraneous variables, and controlling variables in an experiment. The second indicator is interpreting data, which consists of identifying relationships between variables based on graphs or tables, synthesizing the result of observation, and drawing a conclusion based on data obtained from an object pattern. The third indicator, which is formulating hypotheses, contains two descriptors that are identifying questions or opinions that can be tested and formulating questions or predicting the result of an experiment. The fourth indicator is defining operational terms, which consists of determining how to measure research variables, 
defining research variables based on research interventions, and formulating the significance of the research. The fifth indicator, which is experimenting, includes identifying objects to be measured or compared in an investigation or an experiment, determining the appropriate design for the investigation or research to test the hypotheses, and using proper equipment to experiment [7].

Science learning can be more meaningful if the acquisition of skills or knowledge is framed in the constructivism paradigm. Learning environments should be created in such a way so that learning objectives can be achieved, and science process skills can be promoted [6]. RICOSRE learning model is expected to be able to develop students' science process skills. RICOSRE learning model is organized to improve students' higher-order thinking skills. The effectiveness of RICOSRE in enhancing students' critical thinking skills, science literacy, and scientific argumentation skills has been evident [8]; however, the effect of RICOSRE on science process skills have not been ultimately revealed.

RICOSRE learning syntax consists of reading, identifying the problem, constructing the solution, solving the problem, reviewing the solution, and extending the solution [8]. The first syntax, which is reading, engages students in activities for reading literature or articles that contain information related to the concept being learned. Reading is the coordination of affective and cognitive aspects that involves observation, focus, perception, memory, synthesis, analysis, and interpretation [9]. The second syntax of RICOSRE is identifying the problem based on an analysis of the content being learned as the first step to solving the problem [10], [11]. The result of the problem identification should be recorded by the students to proceed to the next stage.

The third syntax is constructing the solution. At this stage, the students are allowed to explore and discover various alternative solutions from different aspects. The solution can be presented in the form of a temporary hypothesis or assumption [12]. This stage allows the students to learn to generate effective strategies to solve problems.

The fourth syntax is solving the problem. At this stage, the best solution picked by the students is applied to solve the problem. This problem-solving activity is useful for the students since it involves thinking skills [13]. This syntax is then followed by the fifth syntax that is reviewing the solution. At this stage, the students discuss and share their ideas with other students to get feedback. They are also given a chance to elaborate on the result of the investigation and solution tryout. Exchanging ideas to construct solutions to problems creatively is perceived as a cognitive process that can have implications on students' literacy development and creative thinking [14]. Findings from the fifth stage are then used in the sixth syntax that is extending the solution. At this stage, students are provided with an opportunity to reflect on whether the solution has fulfilled the desirable condition or goal. The students are also allowed to make comparisons between alternative solutions. This activity is categorized into reflective thinking activity, which constitutes a part of higher-order thinking.

Based on the previous description, it is clear that students' science process skills can be promoted or empowered through RICOSRE. The current study aimed to investigate: 1) an increase in students' science process skills during the implementation of RICOSRE, and 2) the effect of RICOSRE on students' science process skills in a Protists classroom. It was hypothesized that there was a difference between the participants' pretest and post-test scores in science process skills after the implementation of RICOSRE learning model.

\section{METHOD}

\subsection{Design of the Study}

A mixed-methods concurrent triangulation model was employed in this study, which means that the qualitative (QUAL) and quantitative (QUAN) data were given equal priority. Both QUAL and QUAN data were considered as the primary data [15] and used to reveal the improvement of the students' science process skills after the implementation of RICOSRE learning model [16]. These data (QUAL and QUAN) were gathered using essay pre-, mid-, and post-tests. The concurrent triangulation design of this study is presented in Figure 1.

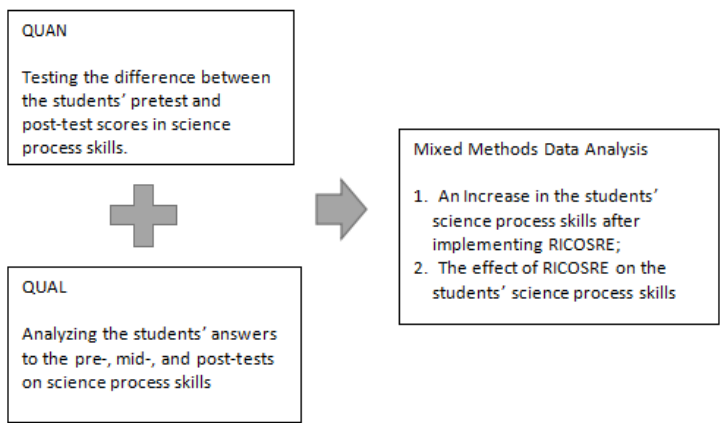

Figure 1. Concurrent triangulation design

\subsection{Participants of the Study}

The purposive sampling method was used to select the participants of the study. They consisted of 31 students who were enrolled in Protista course in the even semester of 2018/2019 at the Department of Biology, Faculty of Mathematics and Natural Sciences, Universitas Negeri Malang.

\subsection{Instruments}

The instruments of the study were divided into instruments for treatment and instruments for measurement. Instruments for treatment were comprised of Course Outline and RICOSRE-based Student Worksheet. This instrument for treatment has been through construct and content validity, which has shown the syntax of the RICOSRE learning 
model visible. Instruments for measurement consisted of essay tests used to evaluate the students' science process skills. Such in case with instrument for treatment, these questions for essay test has been through logic validity. The assessment was carried out through pre-, mid-, and posttests. The participants' answers to the test questions were scored based on the science process skill rubric suggested by [7].

\subsection{Qualitative (QUAL) Approach}

This study employed a qualitative approach to data collection and data analysis. The qualitative data were obtained using a pretest, a mid-test, and a post-test. The students' answers were compared to the indicators and descriptors of science process skills [7]

\subsection{Quantitative (QUAN) Approach}

The quantitative data were gathered using a pretest and a post-test. A one-group pretest-posttest design was employed in this study. The students' pretest and post-test scores were analyzed using a t-test. The main prerequisite for a t-test is a normality test. Therefore, a normality test was conducted before going for the t-test. If the data were distributed normally, a paired sample t-test was performed. Conversely, if data normality and data homogeneity could not be fulfilled, the Wilcoxon test was conducted. The data collected were in the form of the students' science process skills scores evaluated using a rubric [7].

\subsection{Strategies for Data Analysis}

The qualitative and quantitative data were identified and analyzed separately. The results of the analyses were then combined and interpreted together [17] to draw an accurate conclusion on the students' science process skills.

\section{RESULTS AND DISCUSSION}

\subsection{The Quality of the Students' Science Process Skills after RICOSRE}

The analysis of the qualitative (QUAL) data as the primary data to reveal the profile of the students' science process skills was conducted by comparing the students' answers with the science process skills indicators. The result of the analysis showed that there was a change in the students' score pattern from the pretest, mid-test, and post-test. The excerpts below contain examples of the students' unsatisfactory and fruitful answers to the tests' questions.

Pretest Question: Phytophthora infestans is a Protist that can cause the late blight disease or decay in potato plants. This microorganism leaves white spots on the potato leaves that can spread throughout the body of the potato, then decompose the leaves and stems and stop the process of photosynthesis. This disease constitutes a significant problem in various countries. Fungicides application is the most common solution to this problem, but limited access to fungicides and fungus resistance to fungicides results in the inability to stop the disease from spreading continuously. What solutions can you provide to overcome this problem?" S's Answer: By applying environmentally friendly pesticides that can destroy or eliminate bacteria/viruses that cause the late blight disease

It was apparent that S's answer did not yet correspond with all of the science process skills indicators. The student seemingly answered the question spontaneously without undergoing scientific thinking.

G's Answer: The solution is to find a new fungicide to eradicate white spot fungus on potatoes, which can cause complete rotting of the tubers. This fungicide should be composed of natural substances so that it does not damage the soil structure due to the excessive use of chemicals.

Similar to S's answer, G's answer was not yet able to depict the student's science process skills. Therefore, to examine their improvement, the students' answers to the mid-test questions which were more focused on science process thinking activity were analyzed, such as presented below.

Midtest Question: Yuna and Lia want to investigate different types of algae at various pool depths. These algae will be bred for microscopic observation.

a) Design the research and the procedures for collecting the algae samples that can represent three different pool depths, and describe how to do the sampling!

b) What do you do to keep the breeding algae alive?

c) What are the main characteristics that must appear to show that what is observed is algae?"

S's Answer: a) The research is carried out in the same place but with different depths. The observation procedure starts by measuring the depth of the sampling location. Then, based on the result of this measurement, the three different depth points can be identified and marked. Once divided and marked, sampling can be done. Sampling is done by scooping or taking the algae directly by using bottles or other tools.

b) The algae should be placed under direct sunlight and in a nourishing environment, such as clean fishpond water. The algae have the body of the talus, with a variety of forms of plant-like protists, c) -

The student's answer above showed that the indicator of identifying and controlling research variables had been fulfilled through the ability of the student to identify independent variables, identify dependent variables, identify control variables, identify extraneous variables, and control variables in an experiment. The fourth indicator of 
science process skills that are defining operational terms was also depicted in the student's answer through the student's ability to determine how to measure research variables. Unfortunately, this answer had not accommodated other indicators of science process skills. G's Answer:

a) Research design:

- Determine the sampling location (a pond)

- Measure and record the depths

- Take the samples from each of the pond depths

- Put the algae on the prepared media

- Observe the algae samples

- Record the result of the observations

b) Nourish the algae and make sure that the algae get enough nutrients from the pond water, enough air by punching holes in the cover, and enough sunlight.

c) Algae are different from mosses because mosses belong to the kingdom of Plantae (Bryophyta), while algae are plant-like protists that do not belong to the kingdom of Plantae.

The first indicator of science process skills that is identifying and controlling variables appeared in G's answer. Out of the five descriptors, G's answer only represented the student's ability to identify independent, dependent, control, and extraneous variable, while controlling variables was not depicted in the answer.

The pretest and post-test were composed of similar questions. However, the following excerpt showed a change in student S's mindset when answering the same question. S's Answer: Late blight is indeed difficult to overcome. However, we can make various efforts to prevent late blight in potato plants by clearing the land from plant debris, planting healthy tubers, soaking the tubers first in a pesticide solution, and uprooting or burning plants that have been stricken with the disease. After that, the potatoes can be replanted in rotation, and the maintenance of the land should be prioritized.

Student S's answer above contained the indicators of identifying and controlling variables, formulating hypotheses, and defining operational terms. The student was able to identify independent, dependent, control, and extraneous variables. Student $\mathrm{S}$ was also able to control variables in an experiment. Also, student $S$ could successfully identify the problem and questions as well as make a prediction. Furthermore, student $\mathrm{S}$ also showed the ability to measure research variables, define research variables, and make meaningful and understandable formulation.

G's Answer: $\quad$ Using fungicides composed of chemicals can cause pest resistance; therefore, the alternative solution is to eradicate pests/fungi naturally. Some actions that can be done include using fungicides composed of organic materials, carrying out soil conservation/soil sterilization so that it is free from fungus, or by planting on healthy soils with antifungal susceptibility.
The first indicator that is identifying and controlling research variables was shown in the student's answer. Based on the answer, it was evident that student $G$ was able to identify independent, dependent, control, and extraneous variables as well as control the variables. The fourth indicator that is defining operationally was also indicated in the student's answer. Student $G$ showed the ability to determine how to measure research variables, define variables based on the research treatment, and make meaningful and understandable formulation.

The result of the descriptive analysis indicated that the students' average score improved by $19.10 \%$ from the pretest to the mid-test (from 38.84 to 50.53 ) and $20.83 \%$ from the mid-test to the post-test (from 50.53 to 60.83). It can be concluded that there was a $35.94 \%$ increase in the students' average score from the pretest to the post-test. The result of the analysis can be seen in Table 1 .

Table 1. Paired Samples Statistics

\begin{tabular}{|c|c|c|c|c|}
\hline & Mean & $\mathrm{N}$ & $\begin{array}{c}\text { Std. } \\
\text { Deviation }\end{array}$ & $\begin{array}{l}\text { Std. Error } \\
\text { Mean }\end{array}$ \\
\hline $\begin{array}{l}\text { Pre-test } \\
\text { Science } \\
\text { Process Skills }\end{array}$ & 38.84 & 31 & 15.32 & 2.75 \\
\hline $\begin{array}{l}\text { Post-test } \\
\text { Science } \\
\text { Process Skills }\end{array}$ & 60.83 & 31 & 11.06 & 1.98 \\
\hline
\end{tabular}

The improvement of the students' science process skills through RICOSRE was indicated by the results of the descriptive (QUAN) and qualitative (QUAL) analyses. There was an increase in the students' average score from the pretest to the mid-test and from the mid-test to the posttest. The statistics were also supported by an analysis of the science process skills indicators achieved by the students. These findings suggest that the students have shown the ability to think at a higher-order level, process information, and formulate solutions to problems [4]. It was also found that the students were able to think scientifically to solve various problems. This scientific thinking skill can be used by the students to deal with challenges in their daily life [5].

\subsection{The Effect of RICOSRE Learning Model on the Students' Science Process Skills}

The quantitative data were obtained from the results of the pretest and post-test. The normality of the data was tested using a normality test. The results of the normality tests conducted on the students' pretest and post-test scores showed that the data were distributed normally with sig. $(0.066)>0.05$ and sig. $(0.167)>0.05$, respectively. Thus, data analysis could be performed using parametric statistics. A paired-samples t-test was done to investigate the difference between the students' pretest and post-test scores. The result of the t-test analysis was presented in Table 2 . 
Table 2. Paired-Sample t-test

\begin{tabular}{|c|c|c|c|c|c|}
\hline & & $\begin{array}{l}\text { Paired Differences } \\
\text { 95\% Confidence } \\
\text { Interval of the } \\
\text { Difference } \\
\text { Upper }\end{array}$ & $\mathrm{t}$ & df & Sig. (2-tailed.) \\
\hline Pair 1 & $\begin{array}{l}\text { Pretest Science Process Skills - } \\
\text { Post-test Science Process Skills }\end{array}$ & -16.94747 & -8.915 & 30 & .000 \\
\hline
\end{tabular}

Based on the result of the paired-sample t-test, it was found that sig. $(0.000)>0.05$; therefore, the research hypothesis, which stated that there was a difference between the students' pretest and post-test scores, was accepted. The students' average score in the post-test was higher than that in the pretest; then, it can be concluded that RICOSRE learning models had a positive effect on the students' science process skills. This finding implies that the students possess the ability to identify problems, conduct an observation, do an analysis, formulate a hypothesis, draw a conclusion, and implement their knowledge in real-world contexts [5]. It also suggests that students have developed physical and mental skills to collect and manage information in various ways. These skills can be used by the students to predict and explain a phenomenon as well as solve a problem [5]. Science process skills are beneficial for processing new information in a real-world context. Equipped with these skills, it is believed that the students will be able to construct a new concept and understanding of science [18].

Based on the findings of this study, it is clear that the RICOSRE syntax contributes positively to the students' science process skills. The first syntax, which is reading, engages the students in reading activities to prepare themselves before coming to the classroom. This syntax accommodates all the indicators of science process skills. Reading stimulates the thinking process and promotes students' positive attitudes toward science. Reading requires critical thinking, analysis skills [19], and problem-solving skills. Therefore, through reading, the students can gain a meaningful learning experience, apply science process skills, and construct information in science[6].

The second syntax is identifying the problem. At this stage, the students are trained to recognize problems found in science-related literature and encouraged to provide solutions to the problems [8]. The students are expected to be active in the problem-solving process so that learning can be more meaningful. This activity can also help the students improve the ability to explain a scientific phenomenon, design a scientific investigation, and evaluate it [20].

The third syntax that is constructing the solution to the problem requires the students to interact and discuss with their peers to evaluate alternative solutions that they have prepared earlier. This activity aims to generate a more relevant, focused, and comprehensive solution to the problem [20]. The group discussion can facilitate the achievement of the third indicator of science process skills that are formulating a hypothesis (descriptors: identifying questions or opinions that can be tested and formulating questions that can be tested in an experiment) [7]. Constructing the solution is part of an effective problemsolving process. This syntax accommodates activities to fulfill the third indicator of science process skills that consists of determining how to measure research variables, defining research variables, and make meaningful and understandable formulation [7].

The fourth syntax that is solving the problem motivates the students to execute their plan to solve the problem. At this stage, the students are allowed to express their opinions and develop strong arguments [21]. By solving the problem, the students are trained on how to build their knowledge, understand scientific methods, and develop science process skills [6]. This syntax facilitates the achievement of the fifth indicator of science process skills that are experimenting (descriptors: identifying objects to be measured or compared in an investigation or an experiment, determining the appropriate design for the investigation or experiment to test the hypotheses, and using proper equipment to experiment). The students will be encouraged to use effective strategies to look for relevant information that can be used to solve the problem and synthesized information from various sources [22]

The fifth syntax that is reviewing the problem solution trains the students to evaluate the solution in terms of its accuracy, quality, and deficiency compared to other alternative solutions. This stage also empowers the students to assess, compare, and contrast various solutions to find the best [22]. The effectiveness of the solution produced at this stage needs to be re-examined in the following stage because, in a real-world context, there is no one single solution to a problem [23].

At the sixth syntax that is extending the problem solution, the students are encouraged to apply the solution to a similar problem found in a different context to ensure the effectiveness of the solution. Compared to the memorization techniques, the development of science process skills is more effective in helping the students solve problems, think critically, make a decision, and provide an answer to their curiosity [6].

RICOSRE learning model has been proven able to develop students' science process skills and thinking skills through its syntax. Despite its apparent benefits, the effectiveness of 
RICOSRE should be examined further using different instruments, and similar future research should involve more variables such as communication and collaboration that have not been covered in this study.

\section{CONCLUSION}

The results of the study showed that RICOSRE learning model affected college students' science process skills. The syntax of RICOSRE that consists of reading, identifying the problem, constructing the solution, solving the problem, reviewing the solution, and extending the solution was able to improve the students' science process skills in identifying and controlling variables, interpreting data, formulating a hypothesis, defining operationally, and conducting an experiment.

\section{ACKNOWLEDGMENT}

This research is a part of 4in1 IsDB Research Project and funded by PUIPT Disruptive Learning Innovation of Universitas Negeri Malang with contract No. 26.3.25/UN32.14.1/LT/2019.

\section{REFERENCES}

[1] M. Mutlu and B. K. Temiz, "Science Process Skills of Students Having Field Dependent and Field Independent Cognitive Styles.," Educ. Res. Rev., 2013.

[2] A. O. Akinbobola and F. Afolabi, "Analysis of Science Process Skills in West African Senior Secondary School Certificate Physics Practical Examinations in Nigeria," Am. J. Sci. Res., vol. 5, no. 4, pp. 234-240, 2010.

[3] R. Ergül, Y. Simsekli, S. Çalis, Z. Özdilek, G. Sirin, and M. Sanli, "The Effects Of Inquiry-Based Science Teaching On Elementary School Students' Science Process Skills And Science Attitudes," Bulg. J. Sci. Educ. Policy, vol. 5, no. 1, pp. 48-69, 2011.

[4] S. Karamustafaoğlu, "Improving the Science Process Skills Ability of Science Student Teachers Using I Diagrams," Eurasian J. Phys. Chem. Educ, vol. 3, no. 1, pp. 26-38, 2011.

[5] L. N. Nworgu and V. V. Otum, "Effect of Guided Inquiry with Analogy Instructional Strategy on Students Acquisition of Science Process Skills," vol. 4, no. 27, pp. 35-41, 2013.

[6] R. A. A. Rauf, M. S. Rasul, A. N. Mansor, Z. Othman, and N. Lyndon, "Inculcation of science process skills in a science classroom," Asian Soc. Sci., vol. 9, no. 8, pp. 47-57, 2013.
[7] M. N. Sheeba, "An Anatomy of Science Process Skills In The Light Of The Challenges to Realize Science Instruction Leading To Global Excellence in Education," Educ. Confab, 2013.

[8] S. Mahanal, S. Zubaidah, I. D. Sumiati, T. M. Sari, and N. Ismirawati, "RICOSRE: A Learning Model to Develop Critical Thinking Skills for Students with Different Academic Abilities," Int. J. Instr., vol. 12, no. 2, pp. 417-434, 2019.

[9] E. Cer and E. Sahin, "The Effects of Quality Books for Children and the Metacognitive Strategy on Students' Self-Esteem Levels," J. Educ. Learn., vol. 6, no. 1, p. 72, 2016.

[10] G. Thomas and A. Thorne, "How To Increase Higher Level Thinking," Metarie, LA: Center for Development and Learning, 2009. [Online]. Available: https://www.cdl.org/articles/how-to-increase-highorder-thinking/.

[11] R. E. Weiss, "Designing problems to promote higher-order thinking," New Dir. Teach. Learn., 2003.

[12] J. Carson, "A Problem With Problem Solving: Teaching Thinking Without Teaching Knowledge," Math. Educ., vol. 17, no. 2, pp. 7-14, 2007.

[13] M. Kano, Promoting Thinking Skills with ProblemSolving Tasks through Short Stories. 2017.

[14] N. Habibollah, A. Rohani, T. Aizan, S. Jamaluddin, and V. Kumar, "Relationship between creativity and academic achievement: a study of gender differences," J. Am. Sci., 2010.

[15] F. Almeida, "Strategies To Perform a Mixed Methods Study," Eur. J. Educ. Stud., vol. 5, no. 1, pp. 137-151, 2018.

[16] J. W. Cresswell, V. L. P. Clark, M. L. Gutmann, and W. E. Hanson, "An Expanded Typology for Classifying Mixed Methods Research Into Designs," in Handbook of Mixed Methods in Social and Behavioral Research, vol. 36, no. 3, California: Sage Publication, Inc, 2007, pp. 159-196.

[17] D. L. Morgan, "Commentary-After Triangulation, What Next?," J. Mix. Methods Res., vol. 13, no. 1, pp. 6-11, 2019.

[18] T. Mulyeni, M. Jamaris, and Y. Supriyati, "Improving Basic Science Process Skills Through Inquiry-Based Approach in Learning Science for Early 
Elementary Students," J. TURKISH Sci. Educ., vol. 16, no. 2, pp. 187-201, 2019.

[19] M. L. Barton and D. L. Jordan, Teaching Reading in Science: A Supplement to "Teaching Reading in the Content Areas Teacher's Manual (2nd Edition), no. 1. Alexandria: ASCD, 2001.

[20] OECD, PISA 2015 Assessment and Analytical Framework: Science, Reading, Mathematic and Financial Literacy, 2016.

[21] I. Hahn et al., "Assessing scientific literacy over the lifespan - A description of the NEPS science framework and the test development," J. für Bild. Online, vol. 5, no. 2, 2013.

[22] L. Greenstein, “Assessing 21st century skills: A guide to evaluating mastery and authentic learning," Assess. 21st century Ski. A Guid. to Eval. mastery authentic Learn., 2012.

[23] G. Bobish et al., The Information Literacy User's Guide: An Open Online Textbook. 2014. 